Адаменко М. В ${ }^{1}$; Заболотний О. А., к.військ.н., доцент ${ }^{2}$

1 - Командно-штабний інститут застосування військ (сил) Національного університету оборони України імені Івана Черняховського, Київ;

2- Центр воєнно-стратегічних досліджень Національного університету оборони України імені Івана Черняховського, Київ

\title{
Математична модель функціонування органів радіолокаційної розвідки РВіА
}

Резюме. Стаття присвячена опису математичної моделі функціонування органів радіолокаційної розвідки РВіА, яка базується на апараті марковських випадкових процесів та враховує найбільш імовірні стани та переходи між ними, що робить їі більш адекватною дійсному процесу.

Ключові слова: артилерійська розвідка; математична модель; функціонування органів радіолокаційної розвідки; граф станів; система диференціальних рівнянь Колмогорова.

Постановка проблеми. Досвід сучасних війн і військових навчань свідчить про те, що 70-75 \% від загального обсягу задач вогневого ураження противника в операції покладається на ракетні війська і артилерію (РВiА), а в умовах ведення антитерористичної операції на територіях Донецької та Луганської областей (АТО) цей показник сягнув 90-95\% [1-2]. Виконання такого великого обсягу вогневих завдань залежить від ефективності бойового забезпечення бойових дій РВіА.

Найважливішим видом бойового забезпечення бойових дій $\mathrm{PBiA} \epsilon$ артилерійська розвідка (АР). Вона $\epsilon$ сукупністю заходів, які проводяться в артилерійських частинах (підрозділах), 3 метою добування розвідувальних відомостей про противника і місцевість, які необхідні для підготовки і успішного ведення бойових дій PBiA та здійснення ефективного вогневого ураження.

Добування розвідувальних відомостей здійснюється шляхом виконання розвідувальних завдань, для чого зі складу підрозділів АР, артилерійських підрозділів і доданих сил i засобів створюються розвідувальні органи.

Під розвідувальним органом мається на увазі штатний або тимчасово створений підрозділ (група) із необхідними засобами розвідки та управління для виконання визначених розвідувальних завдань.

Таким чином, розвідувальними органами $A P$ - є: особовий склад, озброєння і військова техніка на командно-спостережному пункті; обслуга рухомих розвідувальних пунктів (РРП), командирських машин управління
(КМУ), звукометричних i радіолокаційних комплексів (станцій) (РЛК, РЛС), безпілотних авіаційних комплексів.

Досвід застосування розвідувальних органів АР в АТО свідчить, що найбільших втрат зазнали органи РЛР, які викривалися по радіоелектронному випромінюванню засобами радіотехнічної розвідки противника. Такий характер функціонування призводив до постійних обстрілів позицій РЛС артилерією противника та випадків їх ураження.

Одним із шляхів підвищення живучості органів РЛР $є$ зменшення часу радіоелектронного випромінювання під час ведення розвідки та здійснення маневру між позиціями.

Поряд з цим, відомо, що ефективність виконання вогневих завдань РВіА залежить не тільки від кількості викритих об'єктів противника, а й від якості розвідувальних відомостей, які мають забезпечити прийняття рішення щодо призначення цих об'єктів до ураження.

Якість розвідувальних відомостей в інтересах вогневого ураження противника $\mathrm{PBiA}$ характеризується своєчасністю, достовірністю і точністю визначення координат об' єктів.

При цьому необхідний ступінь якості може бути досягнутий коли об'єкт буде викрито одним органом розвідки не менше трьох разів або коли розвідувальні відомості, що отримані одним органом розвідки з одногодвох виявлень підтверджені іншими органами розвідки, що не завжди є можливим i, таким чином, не дозволяє суттєво скоротити час радіоелектронного випромінювання. Це, в свою чергу, підвищує можливості противника щодо 
викриття органу РЛР i, відповідно, зниженню його живучості.

Отже, в теорії і практиці застосування органів РЛР виникло протиріччя між вимогою підвищення якості розвідувальних відомостей про об' єкти противника в інтересах вогневого ураження PBiA та вимогою забезпечення потрібного рівня живучості органів РЛР за фактором часу радіоелектронного випромінювання, який, 3 одного боку, треба збільшувати для забезпечення якості, i, 3 іншого - скорочувати для забезпечення живучості.

Ступінь розробленості проблеми. На сьогодні існуючі методики оцінювання живучості озброєння в основному спрямовані на визначення можливостей противника щодо викриття цих систем засобами розвідки і безпосереднього їх ураження вогневими засобами. Ці методики враховують вплив вогневих засобів противника на озброєння, але не в повній мірі враховують динаміку функціонування органів РЛР.

Метою статті $\epsilon$ удосконалення моделі функціонування органів РЛР, яка дасть можливість визначити значення показників функціонування органів РЛР для подальшого обгрунтування рекомендацій щодо порядку ведення розвідки для підвищення їх живучості.

Виклад основного матеріалу. Зміст функціонування органів РЛР полягає у виконанні завдань щодо викриття (виявлення) об'єктів противника та передачі розвідувальних відомостей органам управління системи АР. Для добування розвідувальних відомостей про об'єкти противника органи РЛР займають позиції на визначених рубежах (районах), ведуть розвідку об'єктів противника, залишають позиції та здійснюють маневр на інші.

Виходячи $з$ цього, зазначимо, що органи РЛР у процесі свого функціонування можуть знаходитися у таких станах:

"розгортання на позиціях" переводяться із похідного положення в бойове та здійснюють заходи з маскування;

“ведення розвідки” - виявляють об'єкти противника;

“згортання на позиції” - переводяться із бойового положення в похідне;

“зміна позиції" - здійснюють маневр 3 метою виходу з-під можливого вогневого впливу противника;

"під вогневим впливом противника" стан у якому органи РЛР можуть опинитися у разі здійснення вогневого впливу противника по ним.

Для вогневого ураження органів РЛР противник застосовуватиме відповідні вогневі засоби. Органи РЛР являють собою окремі цілі, що уражаються одним вогневим нальотом, $\mathrm{i}$ до ураження яких залучають не менше однієї батареї, що підтверджується досвідом АТО [2].

Таким чином, процес функціонування органів РЛР полягає в послідовній зміні їх функціональних станів під впливом зовнішніх i внутрішніх факторів в умовах вогневого впливу противника.

Аналіз причинно-наслідкових 3в'язків ведення бойових дій показує, що тривалість функціонування органів РЛР хоч і плануються, але $\epsilon$ величиною випадковою. Це свідчить про те, що випадковий процес, який моделюється, може мати кінцеве або нескінченне число можливих станів $S_{1}, S_{2}, \ldots, S_{i}, \ldots, S_{n}$, зміна яких відбувається у часі випадковим чином. Перераховані події (настання фактів перебування органів РЛР у конкретному стані) випадковим чином повторюються у ході бойових дій неодноразово і створюють певний потік подій.

Оскільки жоден із потоків подій не має переваг, то і час в сумарному потоці згідно 3 теоремою про формування найпростішого потоку, можна вважати розподіленими із достатньою для практики точністю за показовим законом розподілу випадкової величини.

Показовий закон розподілу часу дає можливість будувати моделі у класі марковських процесів із безперервним часом i дискретними станами, що дає змогу застосувати метод аналітико-стохастичного моделювання.

Процес функціонування органів РЛР настільки складний, що випадкові фактори будуть присутні в ньому завжди. Хоча планування застосування органів РЛР спрямоване на зниження впливу “випадковості", i надання цьому процесу детермінованого характеру, стохастичну стійкість процесу функціонування органів РЛР у цілому навряд чи можна гарантувати. Тому, для формалізації процесу функціонування органів РЛР необхідно сформулювати деякі припущення, а саме:

результат функціонування органів РЛР завчасно невідомий (можуть бути викриті або невикриті об'єкти противника, уражені або неуражені органи РЛР);

процес функціонування органів РЛР $€$ випадковим; 
маневр органів РЛР із займаних позицій на інші здійснюється у межах визначеної смуги (району) розвідки.

3 опису процесу функціонування органів РЛР та прийнятих припущень можемо перейти до абстрагування від дійсного процесу і перейти до його формалізації.

Кожен описаний вище стан органу РЛР, в якому він може перебувати відобразимо у вигляді певного вузла на графі станів 3 відповідним його позначенням. Лініями, що з'єднують ці вузли, позначимо можливі переходи 3 одного стану в інший, які відбуваються з певними інтенсивностями.

Тоді процес функціонування органу РЛР можна представити у вигляді графу, який наведено на рис. 1.

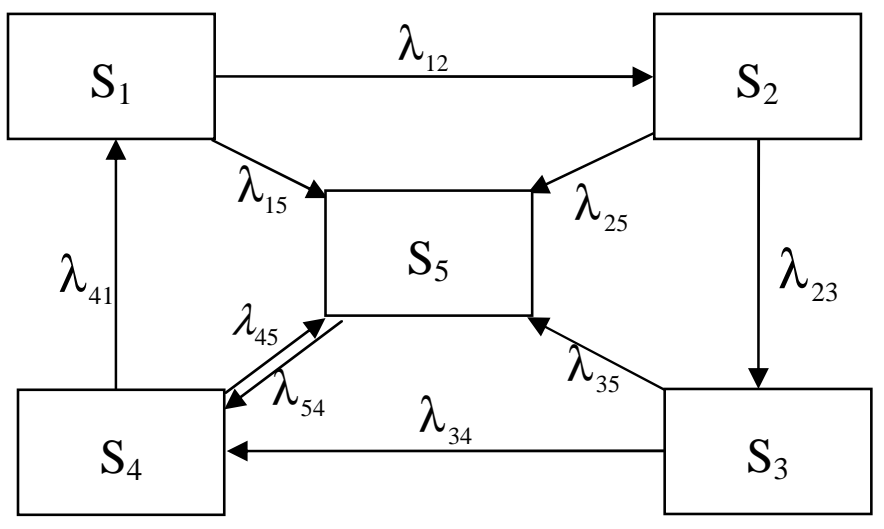

\section{Позначення:}

$\mathrm{S}_{1}$ - стан “розгортання на позиції”;

$\mathrm{S}_{2}$ - стан "ведення розвідки";

$\mathrm{S}_{3}$ - стан "згортання на позиціи”;

$\mathrm{S}_{4}$ - стан “зміна позиції”;

$\mathrm{S}_{5}-$ стан "під вогневим впливом противника";

$\lambda$-інтенсивність переходу із $i$-го стану в $n$-й.

\section{Рис. 1. Граф станів органу РЛР}

Як видно 3 приведеного рисунку, перехід до стану $\mathrm{S}_{5}$ можливий 3 будь-якого іншого стану, а зворотній перехід необхідно здійснити лише у стан $S_{4}$.

Запропонований граф дає змогу формалізувати процес функціонування органів
РЛР та визначити ймовірності перебування їх у конкретних станах залежно від випадкових факторів.

Опишемо цей граф станів за допомогою диференційних рівнянь Колмогорова [8-11]:

$$
\left\{\begin{array}{l}
\frac{d P_{1}(t)}{d t}=-\lambda_{12} P_{1}(t)-\lambda_{15} P_{1}(t)+\lambda_{41} P_{4}(t) \\
\frac{d P_{2}(t)}{d t}=\lambda_{12} P_{1}(t)-\lambda_{25} P_{2}(t)-\lambda_{23} P_{2}(t) \\
\frac{d P_{3}(t)}{d t}=\lambda_{23} P_{2}(t)-\lambda_{35} P_{3}(t)-\lambda_{34} P_{3}(t) \\
\frac{d P_{4}(t)}{d t}=-\lambda_{41} P_{4}(t)-\lambda_{45} P_{4}(t)+\lambda_{34} P_{3}(t)+\lambda_{54} P_{5}(t) \\
\frac{d P_{5}(t)}{d t}=\lambda_{15} P_{1}(t)+\lambda_{25} P_{2}(t)+\lambda_{35} P_{3}(t)+\lambda_{45} P_{4}(t)-\lambda_{54} P_{5}(t)
\end{array}\right.
$$

Кожний і-й стан $\mathrm{S}$ характеризується відповідною ймовірністю $P_{\mathrm{i}}(t)$ перебування в ньому органу РЛР у момент часу $t$.

Для опису процесу функціонування органів РЛР, потрібно розв'язати систему звичайних диференційних рівнянь п'ятого порядку при початкових умовах $P_{1}(0)=1$, $P_{2}(0)=0, P_{3}(0)=0, P_{4}(0)=0, P_{5}(0)=0$.

$$
\sum P_{i}(t)=1
$$

При 3-5 циклах застосування органів РЛР дослідження їх функціонування можна проводити у стаціонарному режимі. $\mathrm{y}$ стаціонарних процесів усі ймовірнісні характеристики не залежать від часу. Для стаціонарного процесу диференціальні рівняння (1) перетворюються у лінійні алгебраїчні рівняння:

$$
\left\{\begin{array}{l}
\left(\lambda_{12}+\lambda_{15}\right) P_{1}=\lambda_{41} P_{4} ; \\
\left(\lambda_{23}+\lambda_{25}\right) P_{2}=\lambda_{12} P_{1} ; \\
\left(\lambda_{34}+\lambda_{35}\right) P_{3}=\lambda_{23} P_{2} ; \\
\left(\lambda_{41}+\lambda_{45}\right) P_{4}=\lambda_{34} P_{3}+\lambda_{54} P_{5} ; \\
\lambda_{54} P_{5}=\lambda_{15} P_{1}+\lambda_{25} P_{2}+\lambda_{35} P_{3}+\lambda_{45} P_{4} .
\end{array}\right.
$$


Для спрощення запису системи алгебраїчних рівнянь (3) доцільно призначити [17]:

$$
\begin{aligned}
& a_{1}=\lambda_{12}+\lambda_{15}, \\
& a_{2}=\lambda_{23}+\lambda_{25}, \\
& a_{3}=\lambda_{34}+\lambda_{35}, \\
& a_{4}=\lambda_{41}+\lambda_{45} .
\end{aligned}
$$

Тоді система алгебраїчних рівнянь (3) виглядатиме:

$$
\left\{\begin{array}{l}
a_{1} P_{1}=\lambda_{41} P_{4} \\
a_{2} P_{2}=\lambda_{12} P_{1} \\
a_{3} P_{3}=\lambda_{23} P_{2} \\
a_{4} P_{4}=\lambda_{34} P_{3}+\lambda_{54} P_{5} ; \\
P_{1}+P_{2}+P_{3}+P_{4}+P_{5}=1 .
\end{array}\right.
$$

Із системи алгебраїчних рівнянь (8) випливають такі залежності для визначення ймовірності станів органів РЛР:

$$
\begin{aligned}
& P_{1}=\frac{\lambda_{41}}{a_{1}} P_{4} \text {, } \\
& P_{5}=1-P_{1}-P_{2}-P_{3}-P_{4} \text {. }
\end{aligned}
$$$$
P_{1}=\frac{\lambda_{41}}{a_{1}}\left(\frac{a_{4} \lambda_{54}}{a_{4}\left(a_{4}+\lambda_{54}\right)-d \lambda_{34}\left(a_{4}+\lambda_{54}\right)+\lambda_{54}\left(8 a_{4}+c a_{4}+d a_{4}+\lambda_{34} d\right)}\right),
$$$$
P_{2}=\frac{\lambda_{12}}{a_{2}} \frac{\lambda_{41}}{a_{1}}\left(\frac{a_{4} \lambda_{54}}{a_{4}\left(a_{4}+\lambda_{54}\right)-d \cdot \lambda_{34}\left(a_{4}+\lambda_{54}\right)+\lambda_{54}\left(6 a_{4}+c a_{4}+d a_{4}+\lambda_{34} d\right)}\right) \text {, }
$$$$
P_{3}=\frac{\lambda_{12}}{a_{2}} \frac{\lambda_{41}}{a_{1}} \frac{\lambda_{23}}{a_{3}}\left(\frac{a_{4} \lambda_{54}}{a_{4}\left(a_{4}+\lambda_{54}\right)-d \lambda_{34}\left(a_{4}+\lambda_{54}\right)+\lambda_{54}\left(6 a_{4}+c a_{4}+d a_{4}+\lambda_{34} d\right)}\right) \text {, }
$$$$
P_{4}=\frac{a_{4} \lambda_{54}}{a_{4}\left(a_{4}+\lambda_{54}\right)-d \lambda_{34}\left(a_{4}+\lambda_{54}\right)+\lambda_{54}\left(6 a_{4}+c a_{4}+d a_{4}+\lambda_{34} d\right)},
$$

Кожний тип органів РЛР має свої характеристики функціонування, звідси слідує, що застосування розвідувальних органів потрібно розглядати для кожного типу окремо.

Момент вмикання апаратури органу РЛР $i$-го типу переводить його зі стану "розгортання на позиціі” у стан “ведення розвідки” 3 інтенсивністю $\lambda_{12}$, яка визначається за формулою:

$$
\lambda_{12}=1 / t_{i}^{\text {po32 }}
$$

де $t_{i}^{\text {pозг }}$ - час розгортання органу РЛР $i$-го типу на позиції.

Момент закінчення обробки розвідувальних відомостей за результатами останнього виявлення об'єкта противника

$$
\begin{gathered}
P_{2}=\frac{\lambda_{12}}{a_{2}} \frac{\lambda_{41}}{a_{1}} P_{4}, \\
P_{3}=\frac{\lambda_{12}}{a_{2}} \frac{\lambda_{41}}{a_{1}} \frac{\lambda_{23}}{a_{3}} P_{4}, \\
B=\frac{\lambda_{41}}{a_{1}}, \\
c=\frac{\lambda_{12} \lambda_{41}}{a_{1} a_{2}}, \\
d=\frac{\lambda_{12} \lambda_{41} \lambda_{23}}{a_{1} a_{2} a_{3}}, \\
P_{4}=\frac{d \lambda_{34}}{a_{4}} P_{4}+\frac{\lambda_{54}}{a_{4}} P_{5}, \\
P_{5}=1-P_{1}-P_{2}-P_{3}-P_{4} .
\end{gathered}
$$

Таким чином, вирази для визначення ймовірності знаходження органів РЛР у станах $S_{1}, S_{2}, S_{3}, S_{4}, S_{5}$ відповідно набувають вигляду: переводить орган РЛР зі стану "ведення розвідки" у стан “згортання на позиції" 3 інтенсивністю $\lambda_{23}$, яка визначається за формулою:

$$
\lambda_{23}=1 / t_{i}^{\text {розя }},
$$

де $t_{i}^{\text {розв }}$ - час ведення розвідки органом РЛР $i$-го типу.

Інтенсивність $\lambda_{34}$, яка переводить орган РЛР $i$-го типу зі стану “згортання на позиціі” у стан “зміна позиціі” можливо визначити як:

$$
\lambda_{34}=1 / t_{i}^{\text {зал }},
$$

де $t_{i}^{\text {зал }}$ - час залишення позиції органом РЛР $i$ го типу, який дорівнює часу переведення органу з бойового положення у похідне. 
Інтенсивність $\lambda_{41}$, яка переводить орган РЛР зі стану “зміна позиціï” у стан “розгортання на позиції” можливо визначити:

$$
\lambda_{34}=1 / t_{i}^{\text {ман }}
$$

де $t_{i}^{\text {ман }}$ - час потрібний на здійснення маневру органу РЛР $i$-го типу з однієї позиції на іншу.

Інтенсивність переходу органу РЛР $i$-го типу у стан перебування під впливом протидії противника $\lambda$, яка переводить їх зі станів $S_{1}, S_{2}, S_{3}, S_{4}$, у стан $S_{5}$ можна визначити таким чином:

$$
\lambda=\frac{1}{t_{n p}^{\text {suкp }}+t_{n p}^{\text {ofp }}+t_{n p}^{\text {в3 }}} P_{n p}^{\text {викp }},
$$

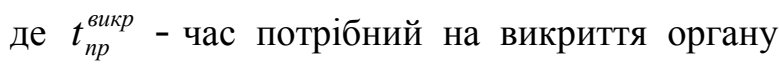
РЛР $i$-го типу засобами розвідки противника;

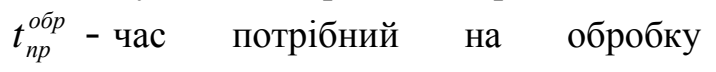
розвідувальних відомостей органам управління противника про викритий орган РЛР $i$-го типу;

$t_{n p}^{83}$ - час виконання вогневого завдання щодо ураження органу РЛР $i$-го типу засобами ВУ противника;

$P_{n p}^{\text {викр }}$ - імовірність викриття противником органу РЛР $i$-го типу.

Значення показника $P_{n p}^{\text {викр }}$ береться відповідно до стану, в якому знаходиться орган РЛР.

Інтенсивність виходу 3-під вогневого впливу противника $\lambda_{54}$, яка переводить орган РЛР $i$-го типу зі стану $S_{5}$ у стан $S_{4}$ можна визначити:

$$
\lambda_{54}=1 / t_{B V}^{n p},
$$

де $t_{B y}^{n p}$ - час вогневого ураження противником органу РЛР.

Отже, функціональні стани органу РЛР $i$-го типу під час його функціонування та отримані ймовірності перебування у цих станах дають можливість знайти МСП часу його перебування у стані “ведення розвідки”:

$$
M_{2}=P_{2} \cdot t_{\text {розв }}^{\text {uикл }},
$$

де $M_{2}$ - МСП часу перебування органу РЛР $i$ го типу у стані “ведення розвідки”;

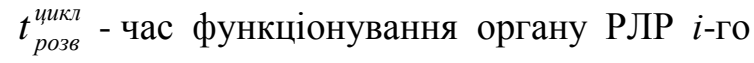
типу протягом одного циклу.

Під одним циклом функціонування органу РЛР $i$-го типу розуміється період часу, який відраховується від моменту початку розгортання у бойове положення на позиції до моменту прибуття на іншу позицію та розраховується:

$$
t_{\text {розв }}^{\text {иикл }}=t_{i}^{\text {розг }}+t_{i}^{\text {розв }}+t_{i}^{\text {зал }}=t_{i}^{\text {ман }} .
$$

Кількість циклів розвідки, які може здійснити орган РЛР $i$-го типу в умовах ведення бойових дій можливо розрахувати:

$$
N_{\text {розв }}^{\text {иикл }}=t_{\text {заг }} / t_{\text {розв }}^{\text {рикл }},
$$

де $t_{\text {заг }}$ - загальний час ведення бойових дій.

Із формули (29) видно, що значення показника $t_{\text {розв }}^{\text {илл } а л е ж и т ь ~ в і д ~ п е в н и х ~ ч а с о в и х ~}$ показників процесу застосування органу РЛР $i$ го типу.

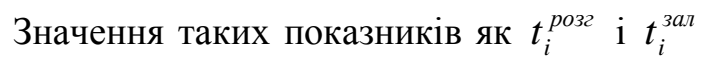
можливо визначити із збірника нормативів 3 бойової підготовки для спеціалістів підрозділів PBiA.

Визначення значення показника $t_{i}^{\text {ман }}$ час здійснення маневру між позиціями можливо здійснити за формулою:

$$
t_{i}^{\text {ман }}=L / V_{i},
$$

де $L$ - відстань між позиціями органу РЛР $i$-го типу;

$V_{i}$ - швидкість органу РЛР $i$-го типу під час здійснення маневру.

Висновки. Отже, дана модель набула подальшого розвитку за рахунок включення до графу функціональних станів органів РЛР: найбільш імовірних станів перебування органів РЛР під час добування розвідувальних відомостей про об'єкти противника; переходів зі стану "під вогневим впливом противника" у стан “зміна позиції”. Цей перехід описує процес здійснення виходу органів РЛР з-під вогневого впливу противника 3 метою забезпечення своєї живучості і створення більш вигідних умов для подальшого ведення розвідки.

Модель функціонування органів РЛР дає можливість визначити показники процесу їх функціонування в умовах ведення бойових дій та у подальшому обгрунтувати рекомендації щодо порядку ведення розвідки для підвищення їх живучості. 
Подальші дослідження у цьому напрямі доцільно присвятити удосконаленню методики визначення раціональних відстаней між позиціями в межах одного рубежу (району) розгортання органу РЛР, яка врахує можливості артилерії противника щодо ураження органу РЛР, обгрунтуванню рекомендацій щодо підвищення живучості органу РЛР за рахунок зменшення часу ведення безперервної розвідки об’єктів противника.

\section{СПИСОК ВИКОРИСТАНОЇ ЛІТЕРАТУРИ}

1. Тенденції розвитку форм і способів застосування ракетних військ і артилерії у локальних війнах та збройних конфліктах останніх десятиліть // Матеріали доповідей науково-практичного семінару кафедри ракетних військ $\mathrm{i}$ артилерії "Перспективи бойового застосування ракетних військ і артилерії ЗС України". - Львів: АСВ,
2015. -86 c.

2. Ракетні війська і артилерія. Досвід, реальність та перспективи. Монографія. - К.: НАОУ, 2007. $227 \mathrm{c}$.

3. Основы исследования операций в военной технике / Ю. В. Чуев, П. М. Мельников, С. И. Петухов, Г. Ф. Степанов, Я. Б. Шор. Под ред. проф. Ю. В. Чуева. - М.: “Советское радио”, 1965. $-592 \mathrm{c}$.

4. Вероятностные методы оценки эффективности вооружения / А. А. Червоный, В.А.Шварц, А. П, Козловцев, В. А. Чобанян. Под ред проф. А. А. Червоного. - М.: Воениздат, 1979. - 95 с.

5. Вентцель Е. С. Исследование операций. - М.: "Советское радио", 1972. - 516 с.

6. Вентцель Е. С. Теория вероятностей. - М.: Наука, 1969. - $416 \mathrm{c}$.

7. Петухов Г. В. Методологические основы внешнего проектирования целенаправленных процессов и целеустремлённых систем / Якунин В. И. - М.: АСТ, 2006. - 504 с.

\section{Стаття надійшла до редакції 22.03.18}

Адаменко М. В ${ }^{1}$;

Заболотний О. А., к.воен.н., доцент ${ }^{2}$

1 - Командно-штабной институт применения войськ (сил) Национального университета обороны Украины имени Ивана Черняховского, Киев;

2 - Центр военно-стратегических исследований Национального университета обороны Украины имени Ивана Черняховского, Киев

\section{Математическая модель функционирования органов радиолокационной разведки РВиА}

Резюме. Статья посвящена описанию математической модели функционирования органов радиолокационной разведки, которая базируется на аппарате марковских случайных процессов и учитывает наиболее вероятностные состояния и переходы между ними, что делает её более адекватной действительному процессу.

Ключевые слова: артиллерийская разведка; математическая модель; функционирование органов радиолокационной разведки; граф состояний; система дифференциальных уравнений Колмогорова.

\section{Adamenko ;}

\section{O. Zabolotny, PhD (Military), assistant professor ${ }^{2}$}

1 - Command and staff institute for the application of troops (forces) of the National Defence University of Ukraine named after Ivan Cherniakhovskyi, Kyiv;

2 - Center for Military and Strategic Studies of the National Defence University of Ukraine named after Ivan Cherniakhovskyi, Kyiv

\section{Mathematical model of the operation of radar reconnaissance bodies in conditions of combat operations}

Resume. The article is devoted to the mathematical model of the functioning of radar reconnaissance organs which is based on the mathematical apparatus of the Markov random processes and takes into account the most probable states and transitions between them making it more adequate to the actual process.

Keywords: artillery intelligence; mathematical model; functioning of radar intelligence agencies; state graphs; Kolmogorov differential equations. 